\title{
Research Article \\ Synthesis and Antimicrobial Activity of Silver Citrate Complexes
}

\author{
Stojan Djokić \\ Elchem Consulting Ltd., Edmonton, AB, Canada T5X $6 B 3$ \\ Correspondence should be addressed to Stojan Djokić, sdjokic@telus.net
}

Received 1 September 2008; Accepted 6 October 2008

Recommended by Ming Yang

Formation of silver citrate/citric acid complexed solutions was investigated. Although, silver citrate is minimally soluble in water, it can successfully be dissolved in citric acid solutions. The maximum concentration of $\mathrm{Ag}(\mathrm{I})$ in solution is estimated at 23 to $25 \mathrm{~g} / \mathrm{L}$ if the concentration of citric acid is at least $4 \mathrm{~mol} / \mathrm{L}$ or higher. The dissolution of silver citrate in citric acid solutions was attributed to the formation of silver citrate complexes of a general formula $\left[\mathrm{Ag}_{3}\left(\mathrm{C}_{6} \mathrm{H}_{5} \mathrm{O}_{7}\right)_{n+1}\right]^{3 n-}$. The silver citrate/citric acid solutions, containing more than about $13 \mathrm{~g} / \mathrm{L} \mathrm{Ag}^{+}$ion, have exhibited a decrease in $\mathrm{Ag}(\mathrm{I})$ concentration in solution over time, due to crystallization. The crystallization product was attributed to the formation of $\left[\mathrm{Ag}_{3} \mathrm{C}_{6} \mathrm{H}_{5} \mathrm{O}_{7}\right]_{x} \cdot n \mathrm{H}_{2} \mathrm{O}$. Importantly, the diluted silver citrate/citric acid complexed solutions have exhibited very strong bacteriostatic and bactericidal activities.

Copyright (c) 2008 Stojan Djokić. This is an open access article distributed under the Creative Commons Attribution License, which permits unrestricted use, distribution, and reproduction in any medium, provided the original work is properly cited.

\section{INTRODUCTION}

It is well established that only silver in its ionic or complexed forms is antimicrobially active, while the elemental silver, even in the so-called "nanocrystalline" state is not [1]. Silvercontaining compounds are attractive because of the fact that in the range of the applicable concentrations, silver ions do not exhibit toxicity and carcinogenic activities [2].

Various forms of silver and its compounds have been investigated in the past few decades due to the antimicrobial activity of silver ions, and there is an increased interest in the potential use of silver(I) as a therapeutic agent for different antimicrobial applications. Researchers have found out that in the treatment of infections the availability of silver ions is completely independent on the total amount of silver chelates [3]. The silver complexes, for example, silver chelates have been described as more effective therapeutic agents than free silver ions [4].

A few amino acids with $\mathrm{N}$ - and $\mathrm{O}$-donor ligands, which show a very wide spectrum of effective antimicrobial activities against bacteria and yeast, were used to obtain watersoluble silver complexes [5]. O-donor ligands, such as $\alpha$ hydroxycarboxylic acids (mandelic, glycolic, malic, tartaric, etc.) also form complexes with $\mathrm{Ag}(\mathrm{I})$.

It was disclosed in the literature that simple carboxylic acids show an unexpected ability to enhance the antimicrobial power of a wide range disinfectants and/or antibiotic agents [6]. The presence of sodium citrate was demonstrated to be necessary to yield potent inhibition of growth of certain pathogenic organisms [7]. Similarly, the antimicrobial antioxidant effects of citrate ions have been confirmed to be very efficient against the proliferation of various spoilage micro-organisms [8]. The taurolidine-citrate solution was suggested as promising combination agent for the prevention of intravascular catheter-related infections [9].

The synthesis, structure, and antimicrobial activity of silver complexes with mandelic acid were described in the recent publication [10]. The silver mandelate compound was found to be a very successful agent against Mycobacterium tuberculosis.

It is believed that a combination of $\mathrm{Ag}^{+}$ions with citrate ions $\left(\mathrm{C}_{6} \mathrm{H}_{5} \mathrm{O}_{7}{ }^{3-}\right)$ can be very attractive for the future biomedical or pharmaceutical/therapeutic applications. Based on the literature review, it is reasonable to assume that silver citrate complexes would act synergistically as antimicrobial agents (due to the presence of $\mathrm{Ag}(\mathrm{I})$ ions) and also as enhancers of antimicrobial activity, antioxidants, and anticancer agents (due to the presence of $\mathrm{C}_{6} \mathrm{H}_{5} \mathrm{O}_{7}{ }^{3-}$ ions) [1-10].

Silver citrate is a white substance with a very limited solubility in water. Under the normal physicochemical 
conditions, 1 part of silver citrate is soluble in 3500 parts of water, which corresponds to $285 \mathrm{ppm}$ of $\mathrm{Ag}(\mathrm{I})$ ion in the solution [11].

Dissolution of silver nitrate into citric acid solution or other hydroxycarboxylic acids does not lead to the precipitation silver citrate or other hydroxycarboxylates (e.g., malate, tartrate, lactate, etc.) [12]. In the case of silver nitrate and citric acid, this behavior can be explained by the following reaction:

$$
3 \mathrm{AgNO}_{3}+\mathrm{H}_{3} \mathrm{C}_{6} \mathrm{H}_{5} \mathrm{O}_{7} \longleftrightarrow \mathrm{Ag}_{3} \mathrm{C}_{6} \mathrm{H}_{5} \mathrm{O}_{7} \downarrow+3 \mathrm{HNO}_{3} .
$$

Due to the dissolution of silver citrate in $\mathrm{HNO}_{3}$, the precipitation of $\mathrm{Ag}_{3} \mathrm{C}_{6} \mathrm{H}_{5} \mathrm{O}_{7}$ does not occur. Therefore, it can be concluded that the equilibrium of the reaction (1) is shifted to the left (in the reverse direction).

Silver citrate can successfully be produced using the routes as described in the following text.

(a) Sodium citrate $\left(\mathrm{Na}_{3} \mathrm{C}_{6} \mathrm{H}_{5} \mathrm{O}_{7}\right)$ route:

$$
\mathrm{AgNO}_{3}+\mathrm{Na}_{3} \mathrm{C}_{6} \mathrm{H}_{5} \mathrm{O}_{7} \longrightarrow \mathrm{Ag}_{3} \mathrm{C}_{6} \mathrm{H}_{5} \mathrm{O}_{7} \downarrow+\mathrm{NaNO}_{3} \text {. }
$$

(b) Sodium hydroxide $(\mathrm{NaOH})$ route:

$$
\begin{gathered}
2 \mathrm{AgNO}_{3}+2 \mathrm{NaOH} \longrightarrow \mathrm{Ag}_{2} \mathrm{O} \downarrow+2 \mathrm{NaNO}_{3}+\mathrm{H}_{2} \mathrm{O}, \\
3 \mathrm{Ag}_{2} \mathrm{O} \downarrow+3 \mathrm{H}_{3} \mathrm{C}_{6} \mathrm{H}_{5} \mathrm{O}_{7} \longrightarrow 2 \mathrm{Ag}_{3} \mathrm{C}_{6} \mathrm{H}_{5} \mathrm{O}_{7} \downarrow+3 \mathrm{H}_{2} \mathrm{O} .
\end{gathered}
$$

When an adequate filtration and washing with water is applied during the processing, this route offers a production of silver citrate with a high purity.

(c) Ammonium hydroxide $\left(\mathrm{NH}_{4} \mathrm{OH}\right)$ route:

$$
\begin{aligned}
& \mathrm{AgNO}_{3}+3 \mathrm{NH}_{4} \mathrm{OH} \\
& \quad \longrightarrow\left[\mathrm{Ag}\left(\mathrm{NH}_{3}\right)_{2}\right] \mathrm{OH}+\mathrm{NH}_{4} \mathrm{NO}_{3}+2 \mathrm{H}_{2} \mathrm{O}, \\
& {\left[\mathrm{Ag}\left(\mathrm{NH}_{3}\right)_{2}\right] \mathrm{OH}+2 \mathrm{H}_{3} \mathrm{C}_{6} \mathrm{H}_{5} \mathrm{O}_{7}} \\
& \quad \longrightarrow \mathrm{Ag}_{3} \mathrm{C}_{6} \mathrm{H}_{5} \mathrm{O}_{7} \downarrow+\left(\mathrm{NH}_{4}\right)_{3} \mathrm{C}_{6} \mathrm{H}_{5} \mathrm{H}_{5} \mathrm{O}_{7}+3 \mathrm{NH}_{4} \mathrm{OH} .
\end{aligned}
$$

Since ammonium citrate and ammonium hydroxide are soluble in water, further steps involve filtration and washing, in order to produce pure $\mathrm{Ag}_{3} \mathrm{C}_{6} \mathrm{H}_{5} \mathrm{O}_{7}$.

Other approaches for the production of silver citrate, based on the routes described here, are also possible. They may include silver oxide(s) or any silver salt which can be further manipulated in order to produce silver citrate.

In the present work, synthesis, structure, and some properties of silver citrate $\left(\mathrm{Ag}_{3} \mathrm{C}_{6} \mathrm{H}_{5} \mathrm{O}_{7}\right)$ are discussed. Formation of water-soluble silver citrate complexes, containing as high as $25 \mathrm{~g} / \mathrm{L}$ silver is described. These silver citrate complexed solutions have not been reported in literature. The stability of silver citrate complexed solutions and their antimicrobial activity have also been investigated.

\section{EXPERIMENTAL}

\subsection{Synthesis}

Silver citrate $\left(\mathrm{Ag}_{3} \mathrm{C}_{6} \mathrm{H}_{5} \mathrm{O}_{7}\right)$ precipitate was produced using routes (a), (b), and (c), described in Section 1. These routes are in the further text designated as $\mathrm{Na}_{3} \mathrm{C}_{6} \mathrm{H}_{5} \mathrm{O}_{7}$ (a), $\mathrm{NaOH}$ (b), and $\mathrm{NH}_{4} \mathrm{OH}$ (c), unless otherwise specified. In each route, the stoichiometric amounts of the required chemicals were dissolved in $100 \mathrm{~mL}$ of water. These solutions were then mixed in a $400 \mathrm{~mL}$ beaker and magnetically stirred for 30 minutes. The white precipitate of silver citrate was separated from the solution by filtration, rinsed with water, dried and used for the further analysis.

\subsection{Materials and methods}

In all experiments, reverse osmosis (RO) water and stoichiometric amounts of analytical grade chemicals were used. In order to study the dissolution, specific amounts of silver citrate (as documented in Section 3) were mixed with water or citric acid solutions of various concentrations. The concentration of $\mathrm{Ag}^{+}$ions in the solution was determined after 24 hours, a time for which it is believed that the equilibrium was achieved. Analytical methods employed in the present work have included volumetric determination of total silver in the solution or in the silver citrate precipitate, X-ray diffraction (XRD), differential scanning calorimetry (DSC), and scanning electron microscopy (SEM).

\subsection{Biological screening}

Based on the experimental observations for the dissolution of $\mathrm{Ag}_{3} \mathrm{C}_{6} \mathrm{H}_{5} \mathrm{O}_{7}$ in citric acid solutions, aqueous silver citrate complexes were prepared and used further for testing the stability and for investigating the antimicrobial activity.

Simple bacteriostatic tests [13] against Pseudomonas aeruginosa were used in order to demonstrate antimicrobial activity of silver citrate complexed solutions synthesized in the present work. For this purpose, silver citrate/citric acid solution containing $18 \mathrm{~g} / \mathrm{L}$ silver ions was further diluted with water in order to obtain a solution containing about $100 \mathrm{ppm}$ silver ions. A $100 \mu \mathrm{L}$ of this diluted solution was placed on a sterile $13 \mathrm{~mm}$ Whatman antibiotic assay disk in order to achieve a complete wetting of the disk. The wetted disks were then placed in a Petri dish containing Mueller Hinton agar and seeded with Pseudomonas aeruginosa. After the incubation at $37^{\circ} \mathrm{C}$ for 24 hours, zones of inhibition (areas surrounding the tests samples where bacterial growth is inhibited or does not occur) were examined. The corrected zone of inhibition (CZOI) was calculated by subtracting the diameter of the test sample from the diameter of the zone of inhibition.

The bactericidal activity of silver citrate/citric acid solution containing $100 \mathrm{ppm} \mathrm{Ag}(\mathrm{I})$ was investigated following the standard procedure [14] using Pseudomonas aeruginosa. It is important to note, that for this purpose the originally prepared solution of silver citrate/citric acid containing $18 \mathrm{~g} / \mathrm{L}$ silver ions was further diluted with a $0.1 \%$ citric acid solution. The target was to obtain a solution containing about $100 \mathrm{ppm}$ of $\mathrm{Ag}(\mathrm{I})$ ions in the final dilution. 
TABLE 1: The yield and the silver content in silver citrate produced via different routes.

\begin{tabular}{lcccc}
\hline Route & $\begin{array}{c}\text { Expected } \\
\text { compound }\end{array}$ & Yield \% & Ag content \% & $\begin{array}{c}\text { Theoretical } \\
\text { Ag content \% }\end{array}$ \\
\hline $\mathrm{Na}_{3} \mathrm{C}_{6} \mathrm{H}_{5} \mathrm{O}_{7}$ & $\mathrm{Ag}_{3} \mathrm{C}_{6} \mathrm{H}_{5} \mathrm{O}_{7}$ & 99.25 & 63.06 & 63.13 \\
$\mathrm{NaOH}$ & $\mathrm{Ag}_{3} \mathrm{C}_{6} \mathrm{H}_{5} \mathrm{O}_{7}$ & 98.34 & 62.95 & 63.13 \\
\hline $\mathrm{NH}_{4} \mathrm{OH}$ & $\mathrm{Ag}_{3} \mathrm{C}_{6} \mathrm{H}_{5} \mathrm{O}_{7}$ & 98.75 & 62.50 & 63.13 \\
\hline
\end{tabular}

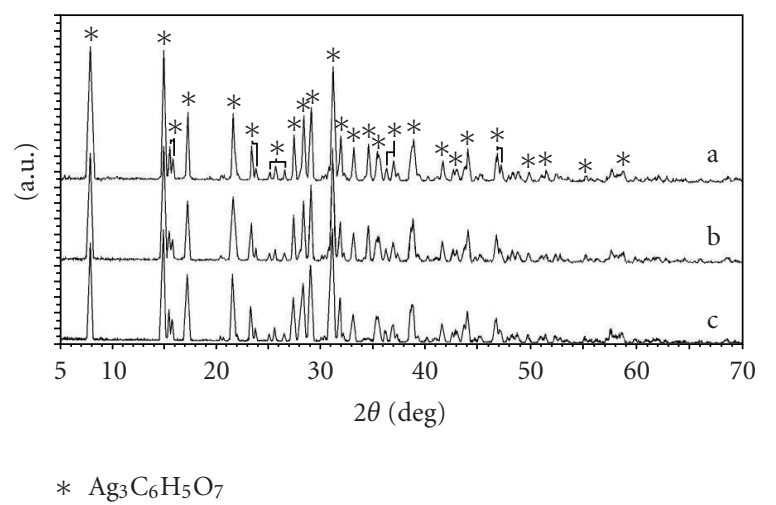

FIgure 1: Comparison of the XRD patterns of silver citrate $\left(\mathrm{Ag}_{3} \mathrm{C}_{6} \mathrm{H}_{5} \mathrm{O}_{7}\right)$ produced via (a) $\mathrm{Na}_{3} \mathrm{C}_{6} \mathrm{H}_{5} \mathrm{O}_{7}$, (b) $\mathrm{NaOH}$, and (c) $\mathrm{NH}_{4} \mathrm{OH}$ routes.

\section{RESULTS AND DISCUSSION}

\subsection{Characterization of silver citrate produced via different routes}

In Table 1 are given results for the yield and silver content in silver citrate obtained by different routes (i.e., via $\mathrm{Na}_{3} \mathrm{C}_{6} \mathrm{H}_{5} \mathrm{O}_{7}$ (a), via $\mathrm{NaOH}$ (b), or via $\mathrm{NH}_{4} \mathrm{OH}$ (c)), as described in Section 1. It is obvious from Table 1 that the yield for the production of $\mathrm{Ag}_{3} \mathrm{C}_{6} \mathrm{H}_{5} \mathrm{O}_{7}$ via different routes is above $98 \%$. Discrepancies from $100 \%$ are related to the experimental error.

The chemical analysis showed that all the samples of silver citrate produced in the present work contained the amount of silver close to the theoretical value of $63.13 \%$, suggesting a relatively high purity of the product.

Overlaid XRD patterns of the $\mathrm{Ag}_{3} \mathrm{C}_{6} \mathrm{H}_{5} \mathrm{O}_{7}$ produced by the routes (a), (b), and (c) are shown in Figure 1. As illustrated in Figure 1, the peaks in the XRD patterns of the white precipitate exactly coincide and match the lines for the $\mathrm{Ag}_{3} \mathrm{C}_{6} \mathrm{H}_{5} \mathrm{O}_{7}$.

In Figure 2 are presented DSC curves of $\mathrm{Ag}_{3} \mathrm{C}_{6} \mathrm{H}_{5} \mathrm{O}_{7}$ produced using $\mathrm{Na}_{3} \mathrm{C}_{6} \mathrm{H}_{5} \mathrm{O}_{7}$ (a), $\mathrm{NaOH}$ (b), or $\mathrm{NH}_{4} \mathrm{OH}$ (c) routes. When silver citrate samples produced in the present work are heated in an argon atmosphere, the obtained DSC curves exhibit a clearly distinguished exothermic maximum in the range from $200^{\circ} \mathrm{C}$ to $210^{\circ} \mathrm{C}$, as illustrated in Figure 2 . The energy of this exothermic process is estimated at about $220 \mathrm{~J} / \mathrm{g}$ for all the tested samples. This exotherm, in analogy with the behavior of other silver salts during heating in an inert environment, is attributed to the decomposition of silver citrate to the elemental silver.

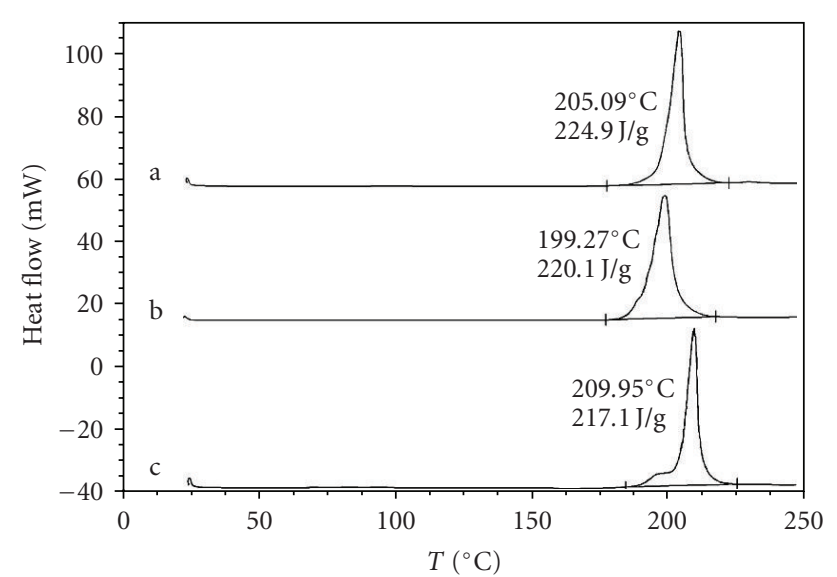

Figure 2: Comparison of DSC curves of silver citrate $\left(\mathrm{Ag}_{3} \mathrm{C}_{6} \mathrm{H}_{5} \mathrm{O}_{7}\right)$ produced via (a) $\mathrm{Na}_{3} \mathrm{C}_{6} \mathrm{H}_{5} \mathrm{O}_{7}$, (b) $\mathrm{NaOH}$, and (c) $\mathrm{NH}_{4} \mathrm{OH}$ routes (heating rate $10^{\circ} \mathrm{C} / \mathrm{min}, \mathrm{Ar}$ atmosphere).

Figure 3 presents SEM micrographs of $\mathrm{Ag}_{3} \mathrm{C}_{6} \mathrm{H}_{5} \mathrm{O}_{7}$ samples produced via $\mathrm{Na}_{3} \mathrm{C}_{6} \mathrm{H}_{5} \mathrm{O}_{7}$ (a), via $\mathrm{NaOH}$ (b), or via $\mathrm{NH}_{4} \mathrm{OH}$ (c) routes. As can be seen from these micrographs, there are no significant differences in the shape of the individual particles of silver citrate produced in different ways. The size of these individual particles is estimated to be in the range from $0.2 \mu \mathrm{m}$ to $0.5 \mu \mathrm{m}$.

\subsection{Dissolution of silver citrate in citric acid solutions}

As mentioned above, silver citrate is very little soluble in water. However, the experiments in the present work have found that silver citrate can quite successfully be dissolved in the citric acid aqueous solutions. This observation is summarized in Figure 4, where a dependence of the concentration of silver ions in solution on the concentration of citric acid, for a fixed amount of silver citrate, is presented. As shown in Figure 4, an increase in the concentration of citric acid, for the fixed amount of $\mathrm{Ag}_{3} \mathrm{C}_{6} \mathrm{H}_{5} \mathrm{O}_{7}$, leads to an increase in the concentration of silver ions in solution. These results strongly suggest that an increase in the concentration of citric acid in solution leads to an increase in the solubility of silver citrate.

The maximum concentration of silver ions in a saturated solution of silver citrate in water can be estimated at about $0.3 \mathrm{~g} / \mathrm{L}\left(2.8 \times 10^{-3} \mathrm{~mol} / \mathrm{L}\right)$, which is in agreement with the literature data [11].

Silver citrate dissociates in aqueous solutions according to the following reaction:

$$
\mathrm{Ag}_{3} \mathrm{C}_{6} \mathrm{H}_{5} \mathrm{O}_{7} \longleftrightarrow 3 \mathrm{Ag}^{+}+\mathrm{C}_{6} \mathrm{H}_{5} \mathrm{O}_{7}{ }^{3-} .
$$

Consequently, the equation for the solubility product of silver citrate can be written as

$$
\mathrm{K}_{\mathrm{sp}(\mathrm{Ag} 3 \mathrm{C} 6 \mathrm{H} 5 \mathrm{O} 7)}=\left[\mathrm{Ag}^{+}\right]^{3}+\left[\mathrm{C}_{6} \mathrm{H}_{5} \mathrm{O}_{7}{ }^{3-}\right] .
$$

Based on the results presented in Figure 4, the solubility product of $\mathrm{Ag}_{3} \mathrm{C}_{6} \mathrm{H}_{5} \mathrm{O}_{7}$ is estimated to be in the order of magnitude $10^{-12}$ to $10^{-11}$. Of course, for a precise determination of the solubility product of silver citrate, more 


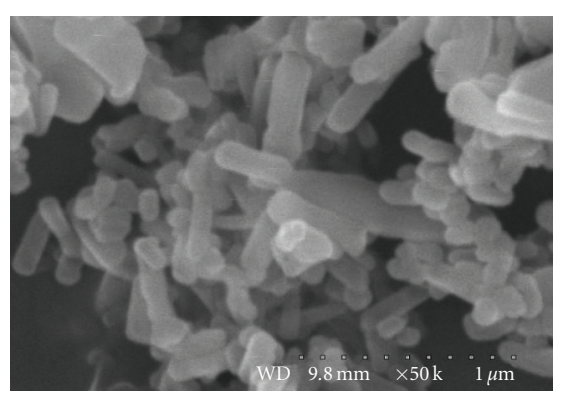

(a)

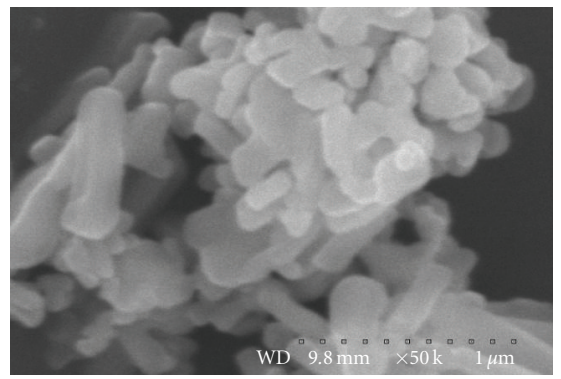

(b)

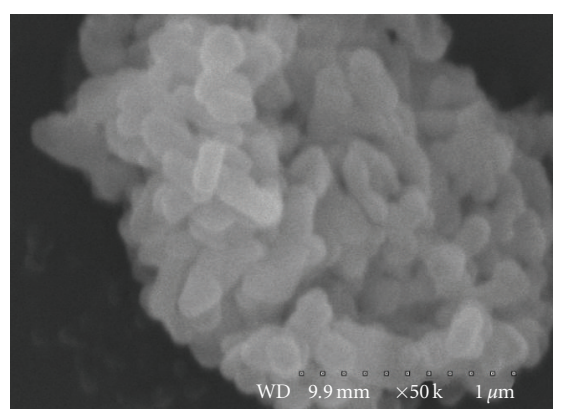

(c)

FIgure 3: Comparison of SEM micrographs of silver citrate $\left(\mathrm{Ag}_{3} \mathrm{C}_{6} \mathrm{H}_{5} \mathrm{O}_{7}\right)$ produced via (a) $\mathrm{Na}_{3} \mathrm{C}_{6} \mathrm{H}_{5} \mathrm{O}_{7}$, (b) $\mathrm{NaOH}$, (c) and $\mathrm{NH}_{4} \mathrm{OH}$ routes (magnifications are given on images).

sophisticated experiments are required. It is to be mentioned that the value of solubility product has not been found in the open literature.

In Figure 5 are presented results of silver ion concentration on the amount of silver citrate dissolved in $50 \mathrm{~cm}^{3}$ solutions with different concentrations of citric acid. Based on the dependences presented in Figure 5, the similar can be concluded as explained above for Figure 4. Generally, in a solution with a constant concentration of citric acid, an increase in the amount of silver citrate leads to an increase in the concentration of silver ions in solution. However, the maximum amount of silver citrate which can be dissolved depends on the citric acid concentration. For example, the maximum amount of silver citrate soluble in a $50 \mathrm{~cm}^{3}$ of $0.5 \mathrm{M}$ citric acid solution is estimated at about $0.4 \mathrm{~g}$, which corresponds to the $\mathrm{Ag}^{+}$ion concentration of about $5 \mathrm{~g} / \mathrm{L}$. A further increase in the amount of silver citrate in a $0.5 \mathrm{M}$ citric acid solution, as illustrated in Figure 5, does not lead to an increase in the concentration of $\mathrm{Ag}^{+}$ions, suggesting that

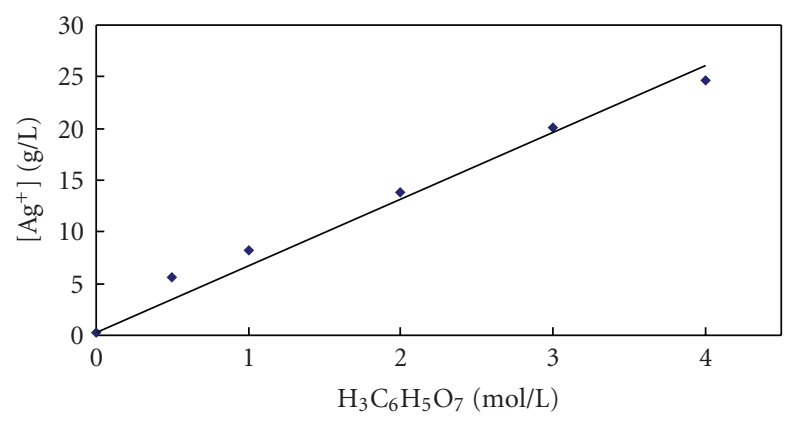

Figure 4: Concentration of $\mathrm{Ag}^{+}$when a constant mass of silver citrate is dissolved in solutions with different citric acid concentrations.

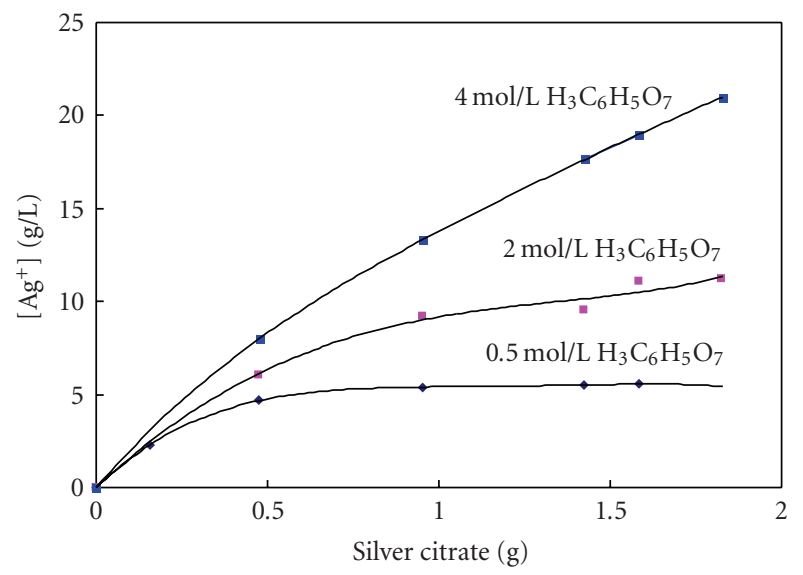

FIgure 5: Concentration of $\mathrm{Ag}^{+}$as a function of the amount of silver citrate dissolved in aqueous solutions of citric acid with different concentrations.

the dissolution does not take place and that the saturation is achieved.

However, a rise in the concentration of citric acid leads to an increase in the amount of silver citrate which can be dissolved. In concentrated citric acid solutions $(3 \mathrm{~mol} / \mathrm{L}$ to $4 \mathrm{~mol} / \mathrm{L}$ ), which corresponds to about 576 to $768 \mathrm{~g} / \mathrm{L}$, the maximum concentration of silver ions is estimated to about $22-25 \mathrm{~g} / \mathrm{L}(0.204-0.232 \mathrm{~mol} / \mathrm{L})$. These concentrations of silver ions correspond to the amount of silver citrate in the range from $34.85 \mathrm{~g} / \mathrm{L}$ to $39.60 \mathrm{~g} / \mathrm{L}$. A further addition of silver citrate to the concentrated citric acid solutions does not lead to dissolution, suggesting that the saturation is achieved. On the other hand, the preparation of citric acid solutions with concentrations more than $4 \mathrm{~mol} / \mathrm{L}$ faces experimental difficulties, even with heating, since the crystallization of citric acid occurs due to the saturation.

How can the dissolution of silver citrate in citric acid solutions be described? Citric acid, $\mathrm{H}_{3} \mathrm{C}_{6} \mathrm{H}_{5} \mathrm{O}_{7}$, contains three carboxylic groups $(-\mathrm{COOH})$ and, consequently, three hydrogen ions can be replaced with metal ions, as it is observed in the precipitation of silver citrate, $\mathrm{Ag}_{3} \mathrm{C}_{6} \mathrm{H}_{5} \mathrm{O}_{7}$. When one or two hydrogen ions from the carboxylic groups of citric acid are replaced with $\mathrm{Ag}^{+}$ions $\mathrm{AgH}_{2} \mathrm{C}_{6} \mathrm{H}_{5} \mathrm{O}_{7}$ or $\mathrm{Ag}_{2} \mathrm{HC}_{6} \mathrm{H}_{5} \mathrm{O}_{7}$ should be produced, respectively. The 
formation of these compounds can be described with the following reactions:

$$
\begin{aligned}
& \mathrm{Ag}_{3} \mathrm{C}_{6} \mathrm{H}_{5} \mathrm{O}_{7} \downarrow+2 \mathrm{H}_{3} \mathrm{C}_{6} \mathrm{H}_{5} \mathrm{O}_{7} \longrightarrow 3 \mathrm{AgH}_{2} \mathrm{C}_{6} \mathrm{H}_{5} \mathrm{O}_{7}, \\
& 2 \mathrm{Ag}_{3} \mathrm{C}_{6} \mathrm{H}_{5} \mathrm{O}_{7} \downarrow+\mathrm{H}_{3} \mathrm{C}_{6} \mathrm{H}_{5} \mathrm{O}_{7} \longrightarrow 3 \mathrm{Ag}_{2} \mathrm{HC}_{6} \mathrm{H}_{5} \mathrm{O}_{7} .
\end{aligned}
$$

Based on the stoichiometry of the reactions (7) and (8) and an assumption that $\mathrm{AgH}_{2} \mathrm{C}_{6} \mathrm{H}_{5} \mathrm{O}_{7}$ or $\mathrm{Ag}_{2} \mathrm{HC}_{6} \mathrm{H}_{5} \mathrm{O}_{7}$ is soluble in water, it can easily be calculated that the amounts of citric acid for the dissolution of $100 \mathrm{~g}$ of $\mathrm{Ag}_{3} \mathrm{C}_{6} \mathrm{H}_{5} \mathrm{O}_{7}$ $(0.195 \mathrm{~mol})$ are, respectively, $74.89 \mathrm{~g}(0.384 \mathrm{~mol})$ for the reaction (7) and $18.72 \mathrm{~g}(0.0975 \mathrm{~mol})$ for the reaction (8).

However, the experimental observations have shown that this is not the case. As experimentally found, significantly larger amounts of citric acid are required for the dissolution of $\mathrm{Ag}_{3} \mathrm{C}_{6} \mathrm{H}_{5} \mathrm{O}_{7}$ than those calculated on the basis of the stoichiometry of the reactions (7) and (8). Consequently, if $\mathrm{AgH}_{2} \mathrm{C}_{6} \mathrm{H}_{5} \mathrm{O}_{7}$ and $\mathrm{Ag}_{2} \mathrm{HC}_{6} \mathrm{H}_{5} \mathrm{O}_{7}$ are soluble in water, it is unlikely that the dissolution of silver citrate proceeds via reactions (7) and (8). On the other hand, chemical analysis of "undissolved" precipitate found that it (precipitate) contained about $63 \% \mathrm{Ag}$, which corresponds to $\mathrm{Ag}_{3} \mathrm{C}_{6} \mathrm{H}_{5} \mathrm{O}_{7}$ (see Table 1) and not to $\mathrm{AgH}_{2} \mathrm{C}_{6} \mathrm{H}_{5} \mathrm{O}_{7}$ or $\mathrm{Ag}_{2} \mathrm{HC}_{6} \mathrm{H}_{5} \mathrm{O}_{7}$.

Considering the fact that significantly larger amounts of citric acid are required for the dissolution of silver citrate, it is reasonable to assume, based on the silver analysis and stoichiometry of the chemical equations, that citric acid produces complexes with silver citrate according to the following reaction:

$$
\begin{aligned}
\mathrm{Ag}_{3} \mathrm{C}_{6} \mathrm{H}_{5} \mathrm{O}_{7}+n \mathrm{H}_{3} \mathrm{C}_{6} \mathrm{H}_{5} \mathrm{O}_{7} & \\
& \longleftrightarrow\left[\mathrm{Ag}_{3}\left(\mathrm{C}_{6} \mathrm{H}_{5} \mathrm{O}_{7}\right)_{n+1}\right]^{3 n-}+3 n \mathrm{H}^{+} .
\end{aligned}
$$

The complexes with a general formula stated as $\left[\mathrm{Ag}_{3}\left(\mathrm{C}_{6} \mathrm{H}_{5} \mathrm{O}_{7}\right)_{n+1}\right]^{3 n-}$, where $n$ is an integer, that is, $n=$ $1,2,3 \ldots$, are expected to be soluble and stable in water. These complexes, of course, should further be studied using spectroscopic and other analytical techniques. On the other hand, the reaction (9) is reversible, and as seen from Figures 4 and 5, depends on both amounts of silver citrate and citric acid concentration. The structure of the proposed $\left[\mathrm{Ag}_{3}\left(\mathrm{C}_{6} \mathrm{H}_{5} \mathrm{O}_{7}\right)_{n+1}\right]^{3 n-}$ complex ion should further be investigated using spectroscopic or other analytical techniques.

\subsection{Stability of silver citrate/citric acid complexes}

The solutions of silver citrate/citric acid have exhibited a relatively good stability. Figure 6 shows a dependence of silver ion concentration on time for a silver citrate dissolved in a $4 \mathrm{~mol} \mathrm{H}_{3} \mathrm{C}_{6} \mathrm{H}_{5} \mathrm{O}_{7}$ solution left to stay for 13 weeks. It is obvious from Figure 6 that the concentration of silver ion in solution decreased from $19 \mathrm{~g} / \mathrm{L}$ to about $13 \mathrm{~g} / \mathrm{L}$ during 4 weeks. A further aging, that is, after 4 weeks, did not lead to any significant changes in the $\mathrm{Ag}^{+}$ion concentration, and as illustrated in Figure 6, it remained practically the same (about $13 \mathrm{~g} / \mathrm{L}$ ). The decrease in the silver ion concentration is attributable to the recrystallization of $\mathrm{Ag}_{3} \mathrm{C}_{6} \mathrm{H}_{5} \mathrm{O}_{7}$ in saturated silver citrate/citric acid solution.

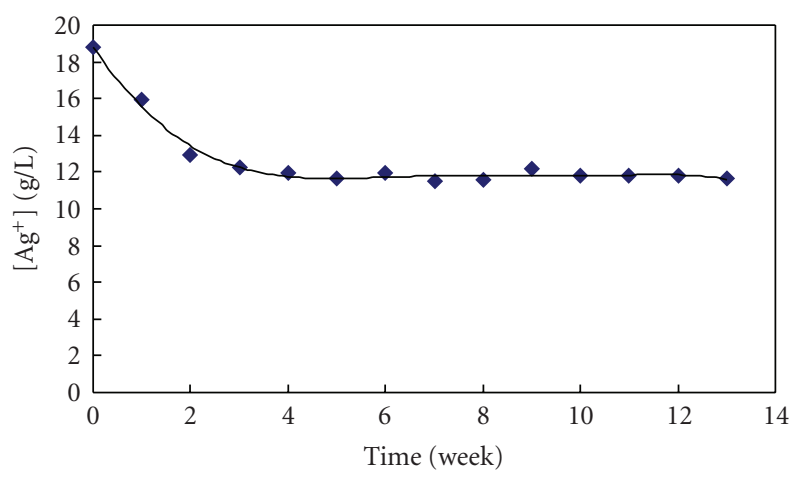

FIgURE 6: Dependence of silver ion concentration on time for a silver citrate complexed solution where the initial $\mathrm{Ag}^{+}$ion concentration was about $19 \mathrm{~g} / \mathrm{L}$.

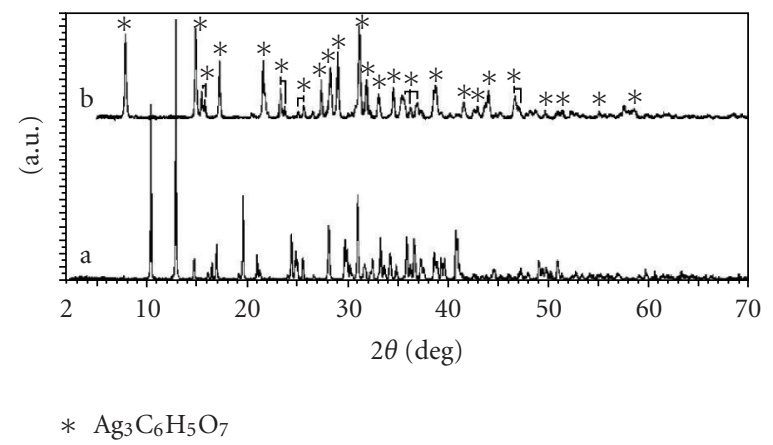

FIGURE 7: Comparison of XRD patterns of crystals produced during the aging of (a) silver citrate/citric acid solutions and (b) silver citrate $\left(\mathrm{Ag}_{3} \mathrm{C}_{6} \mathrm{H}_{5} \mathrm{O}_{7}\right)$ produced via $\mathrm{NaOH}$ route.

Indeed, a precipitation (formation of colorless crystals) in this solution was observed. Chemical analysis has found that these crystals contain about $63 \% \mathrm{Ag}$, which is comparable to the silver content in silver citrate (see Table 1).

Do these crystals, formed during the aging of concentrated silver citrate complexed solutions, really represent $\mathrm{Ag}_{3} \mathrm{C}_{6} \mathrm{H}_{5} \mathrm{O}_{7}$ (one that is produced via routes (a), (b), or (c), described in Section 1)? Based on the XRD patterns obtained for the crystals formed during the aging silver citrate/citric acid complexed solutions, it seems unlikely that these crystals are $\mathrm{Ag}_{3} \mathrm{C}_{6} \mathrm{H}_{5} \mathrm{O}_{7}$. As illustrated in Figure 7, there is a significant difference in the XRD patterns of crystals produced during the aging of silver citrate/citric acid solutions (a) and silver citrate produced via $\mathrm{NaOH}$ route (b).

When considering the interactions of silver(I) with hydroxycarboxylic acids, little information is available in the open literature [15]. In general terms, only weak complexes are formed, with a tendency to undergo reduction to silver(0) in aqueous solutions, as it is seen with ascorbate and tartrate. On the other hand, the citrate ions do not show tendency to be oxidized by the $\operatorname{Ag}(\mathrm{I})$ ions. Despite the resistivity of $\mathrm{Ag}(\mathrm{I})$ ions to be reduced by the citrate, and commercial availability of silver citrate, very little knowledge on this class of compounds is available in the literature. 
Crystals of polymeric ammonium silver citrate hydrate, namely, $\left\{\mathrm{NH}_{4}\left[\mathrm{Ag}_{2}\left(\mathrm{C}_{6} \mathrm{H}_{5} \mathrm{O}_{7}\right)\right]\left(\mathrm{H}_{2} \mathrm{O}\right)\right\}_{n}$ were grown successfully [16]. Similarly, the crystals of silver glycolate hemihydrate $\left(\left[\mathrm{Ag}_{2}\left(\mathrm{HOCH}_{2} \mathrm{CO}_{2}\right)_{2}\right]_{n} \cdot n \mathrm{H}_{2} \mathrm{O}\right)$ [15], or silver mandelate complex [10] formulated as $\left[\mathrm{Ag}\left(\mathrm{C}_{8} \mathrm{H}_{7} \mathrm{O}_{3}\right)\right]_{n}$ have been reported in the literature. Based on the experimental observations, literature $[10,15,16]$ and the fact that the investigated system contained only $\mathrm{H}_{2} \mathrm{O}, \mathrm{C}_{6} \mathrm{H}_{5} \mathrm{O}_{7}{ }^{3-}$ and $\mathrm{Ag}^{+}$can be postulated that the formation of crystals in the saturated silver citrate/citric acid solutions can be described by the following equation:

$x\left[\mathrm{Ag}_{3}\left(\mathrm{C}_{6} \mathrm{H}_{5} \mathrm{O}_{7}\right)_{n+1}\right]^{3 n-} \longrightarrow\left[\mathrm{Ag}_{3} \mathrm{C}_{6} \mathrm{H}_{5} \mathrm{O}_{7}\right]_{x} \downarrow+n \mathrm{C}_{6} \mathrm{H}_{5} \mathrm{O}_{7}^{3 n-}$.

In this way, the XRD pattern presented in Figure 7 (a) can be attributed to $\left[\mathrm{Ag}_{3} \mathrm{C}_{6} \mathrm{H}_{5} \mathrm{O}_{7}\right]_{x}$, or most likely its hydrated form, for example, $\left[\mathrm{Ag}_{3} \mathrm{C}_{6} \mathrm{H}_{5} \mathrm{O}_{7}\right]_{x} \cdot n \mathrm{H}_{2} \mathrm{O}$. It is obvious that further XRD studies are required in order to determine the exact structure of this compound.

Based on the results presented in Figure 6, it was assumed that if the solutions of silver citrate/citric acid are prepared with lower concentration of $\mathrm{Ag}^{+}$, they should exhibit a better stability than the solutions containing more than $15 \mathrm{~g}$ of $\mathrm{Ag}^{+} / \mathrm{L}$. In other words, under these conditions, the precipitation should not be observed, of course, if the concentration of citric acid is sufficient "to allow" the existence of silver citrate complexes in solution. In fact, the originally prepared silver citrate/citric acid solution containing about $20 \mathrm{~g} / \mathrm{L}$ was diluted with water to about $13 \mathrm{~g} / \mathrm{L}$ and left to stay in clear bottles exposed to daylight at room temperature. As shown in Figure 8, changes in the concentration of silver ions in solutions have not been observed for over 10 weeks. Based on the experimental results of the present work, it seems that the silver citrate/citric acid complexed solutions are quite stable for a relatively long period of time, when the concentration of $\mathrm{Ag}^{+}$ion is less than $15 \mathrm{~g} / \mathrm{L}$ and the concentration of citric acid is more than $3 \mathrm{~mol} / \mathrm{L}(576 \mathrm{~g} / \mathrm{L})$. These solutions have not exhibited changes in color and, also, a formation of precipitate did not occur. Contrarily, these solutions were clear and colorless for more than 6 months, suggesting as well a good stability when exposed to light.

\subsection{Antimicrobial activity of silver citrate complexes}

In Figure 9 are shown photographs (after incubation for 24 hours at $37^{\circ} \mathrm{C}$ ) of disks placed onto an agar medium seeded with Pseudomonas aeruginosa. It is obvious that a clear zone surrounding the test sample where bacterial growth does not occur (or is inhibited) was obtained for the antibiotic disk assay wetted with $100 \mu \mathrm{L}$ of silver citrate/citric acid solution containing about $100 \mathrm{ppm} \mathrm{Ag}(\mathrm{I})$ ion. The CZOI was estimated at about $9 \mathrm{~mm}$. This result suggests a strong bacteriostatic activity of silver citrate/citric acid complexed solution.

For comparison, in Figure 9(b) is also shown a photograph of the antibiotic assay disk (not treated with silver citrate/citric acid solutions). In this case, a clear zone surrounding the test sample was not obtained. Contrarily, bacterial growth was observed on the disk.

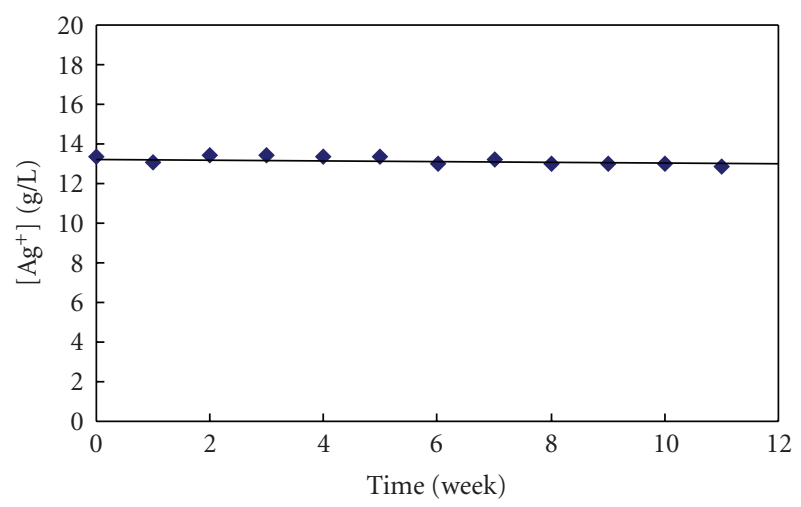

FIGURE 8: Dependence of silver ion concentration on time for a silver citrate complexed solution where the initial $\mathrm{Ag}^{+}$ion concentration was about $13 \mathrm{~g} / \mathrm{L}$.

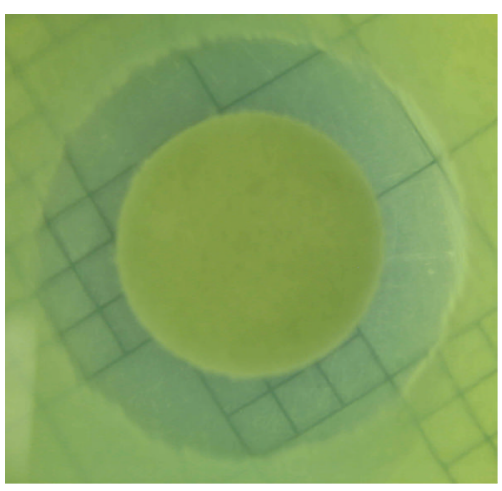

(a)

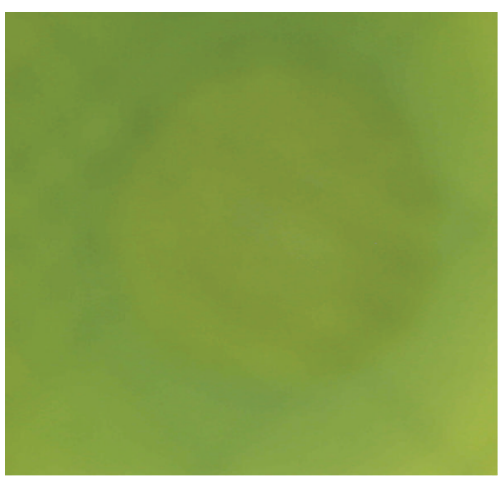

(b)

FIGURE 9: Bacteriostatic activity of (a) silver citrate/citric acid complexed solution and (b) control.

The results of the bactericidal activity are summarized in Table 2. As can be seen from Table 2, a log reduction of 7.39 was achieved with silver citrate/citric acid solution (practically speaking, no surviving organisms were observed), suggesting a total kill of the tested organisms (Pseudomonas aeruginosa). Importantly, the results in Table 2 suggest a very strong bactericidal activity of silver citrate/citric acid solution. On the other hand, silver nitrate solution containing the same concentration of $\mathrm{Ag}(\mathrm{I})$ ion as silver citrate/citric acid 
TABLE 2: Bactericidal activity of silver citrate/citric acid complexed solutions against Pseudomonas aeruginosa (30 minutes exposure).

\begin{tabular}{lccccc}
\hline Sample & $\begin{array}{l}\text { Ag } \\
\text { content } \\
(\mathrm{ppm})\end{array}$ & CFU/plate & $\begin{array}{l}\text { Density } \\
\mathrm{CFU} / \mathrm{mL}\end{array}$ & $\begin{array}{l}\text { Log } \\
\text { density }\end{array}$ & $\begin{array}{l}\text { Log } \\
\text { reduction }\end{array}$ \\
\hline Control & 0 & 27 & & & \\
& & 22 & & & \\
& & 16 & & & \\
$\mathrm{AgNO}_{3}$ & 100 & 18 & $1.7 \times 10^{7}$ & 7.23 & 0.16 \\
solution & & 18 & & & \\
& & 0 & & & \\
Silver & & 0 & 0 & 0 & 7.39 \\
citrate/citric & 100 & 0 & & & \\
acid solution & & 0 & & & \\
\hline
\end{tabular}

solution has shown the log reduction of only 0.16 , suggesting a very low killing rate. This result is in the agreement with the previously observed behavior that the silver complexes (as in the present work, silver citrate/citric acid solutions) are more effective agents than free silver ions (silver nitrate) [4]. It is obvious that silver citrate/citric acid solution has exhibited a superior bactericidal activity over silver nitrate solution.

\section{CONCLUSIONS}

Silver citrate can successfully be deposited using silver nitrate as a source of silver ions and salts of citric acid as sources of citrate ions. Although, silver citrate is very little soluble in water, it can be successfully dissolved in citric acid solutions. An increase in the concentration of citric acid leads to an increase in the amount of silver citrate that can be dissolved. The maximum concentration of $\mathrm{Ag}(\mathrm{I})$ in the solution that can be achieved is estimated at about $23 \mathrm{~g} / \mathrm{L}$ to $25 \mathrm{~g} / \mathrm{L}$ if the concentration of citric acid is at least $4 \mathrm{~mol} / \mathrm{L}$ or higher.

The dissolution of silver citrate in citric acid solutions was attributed to the formation of silver citrate complexes of a general formula $\left[\mathrm{Ag}_{3}\left(\mathrm{C}_{6} \mathrm{H}_{5} \mathrm{O}_{7}\right)_{n+1}\right]^{3 n-}$. These solutions have shown a reasonable stability over time. In concentrated solutions, containing more than $13 \mathrm{~g} / \mathrm{L}$ of $\mathrm{Ag}(\mathrm{I})$ ion, the crystallization was observed. Based on the XRD and chemical analyses, the crystallization product was attributed to the formation of a compound $\left[\mathrm{Ag}_{3} \mathrm{C}_{6} \mathrm{H}_{5} \mathrm{O}_{7}\right]_{x} \cdot n \mathrm{H}_{2} \mathrm{O}$.

Importantly, the diluted silver citrate/citric acid complexed solutions have exhibited very strong bacteriostatic and bactericidal activities.

\section{ACKNOWLEDGMENTS}

This work was financially supported by Exciton Technologies Inc. (Alta., Canada). The author is thankful to Ms. Nada Djokic for the experimental help and Mr. David Lischuk (Exciton Technologies Inc.) for help in the preparation of drawings. Exciton Technologies Inc., assisted in meeting the processing charges for this article.

\section{REFERENCES}

[1] S. Djokić, "Treatment of various surfaces with silver and its compounds for topical wound dressings, catheter and other biomedical applications," ECS Transactions, vol. 11, no. 21, pp. 1-12, 2008.

[2] M. J. Stillman, A. Presta, Z. Gui, and D. T. Jiang, "Spectroscopic studies of copper, silver and gold-metallothioneins," Metal-Based Drugs, vol. 1, no. 5-6, pp. 375-394, 1994.

[3] P. Dibrov, J. Dzioba, K. K. Gosink, and C. C. Häse, "Chemiosmotic mechanism of antimicrobial activity of $\mathrm{Ag}^{+}$in Vibrio cholerae," Antimicrobial Agents and Chemotherapy, vol. 46, no. 8, pp. 2668-2670, 2002.

[4] K. I. Batarseh, "Anomaly and correlation of killing in the therapeutic properties of silver (I) chelation with glutamic and tartaric acids," The Journal of Antimicrobial Chemotherapy, vol. 54, no. 2, pp. 546-548, 2004.

[5] K. Nomiya and H. Yokoyama, "Syntheses, crystal structures and antimicrobial activities of polymeric silver(I) complexes with three amino-acids [aspartic acid $\left(\mathrm{H}_{2}\right.$ asp), glycine (Hgly) and asparagine (Hasn)]," Journal of the Chemical Society, Dalton Transactions, no. 12, pp. 2483-2490, 2002.

[6] E. Shanbrom, "Use of citric acid as antimicrobial agent or enhancer or as anticancer agent," WO/2002/034293, International Application no: PCT/US2001/04245.

[7] M. Blaszyk and R. A. Holley, "Interaction of monolaurin, eugenol and sodium citrate on growth of common meat spoilage and pathogenic organisms," International Journal of Food Microbiology, vol. 39, no. 3, pp. 175-183, 1998.

[8] K. I. Sallam, "Antimicrobial and antioxidant effects of sodium acetate, sodium lactate, and sodium citrate in refrigerated sliced salmon," Food Control, vol. 18, no. 5, pp. 566-575, 2007.

[9] C. B. Shah, M. W. Mittelman, J. W. Costerton, et al., "Antimicrobial activity of a novel catheter lock solution," Antimicrobial Agents and Chemotherapy, vol. 46, no. 6, pp. 1674-1679, 2002.

[10] A. Cuin, A. C. Massabni, C. Q. F. Leite, et al., "Synthesis, X-ray structure and antimycobacterial activity of silver complexes with $\alpha$-hydroxycarboxylic acids," Journal of Inorganic Biochemistry, vol. 101, no. 2, pp. 291-296, 2007.

[11] A. B. Arata, "Disinfectant and method of making," US patent no. $6197814,2001$.

[12] N. Thompson, "Silver," in Comprehensive Inorganic Chemistry, J. C. Bailar Jr., H. J. Emeléus, R. Nyholm, and A. F. TrotmanDickenson, Eds., vol. 3D, Pergamon Press, Oxford, UK, 1973.

[13] J. F. Acar and F. W. Goldstein, "Disk susceptibility test," in Antibiotics in Laboratory Medicine, V. Lorian, Ed., pp. 17-52, Lippincott Williams \& Wilkins, Baltimore, Md, USA, 1991.

[14] A standard quantitative test for determining the bactericidal, virucidal, fungicidal and sporocidal activities of liquid chemical germicides, ASTM International, Designation E 2197-02.

[15] G. Smith, A. N. Reddy, K. A. Byriel, and C. H. L. Kennard, "The crystal structure of silver(I) glycolate hemihydrate," Australian Journal of Chemistry, vol. 47, no. 6, pp. 1179-1183, 1994.

[16] D. S. Sagatys, G. Smith, R. C. Bott, D. E. Lynch, and C. H. L. Kennard, "Preparation and crystal structure of polymeric ammonium silver(I) citrate hydrate, $\left\{\mathrm{NH}_{4}\left[\mathrm{Ag}_{2}\left(\mathrm{C}_{6} \mathrm{H}_{5} \mathrm{O}_{7}\right)\left(\mathrm{H}_{2} \mathrm{O}\right)\right]\right\}$ n, Polyhedron, vol. 12, no. 6, pp. 709-713, 1993. 


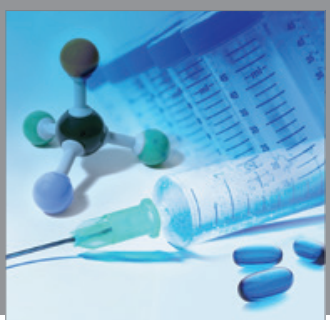

International Journal of

Medicinal Chemistry

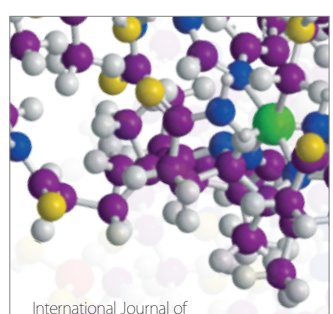

Carbohydrate Chemistry

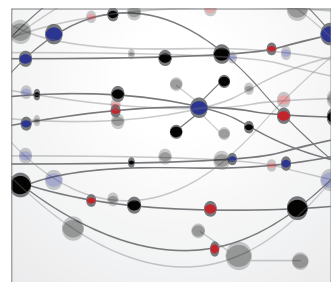

The Scientific World Journal
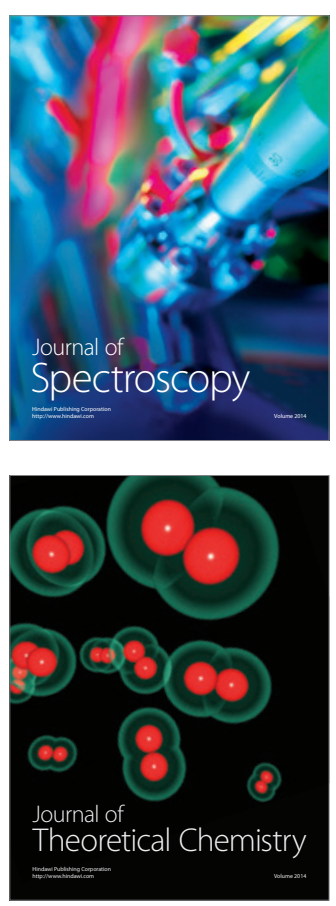
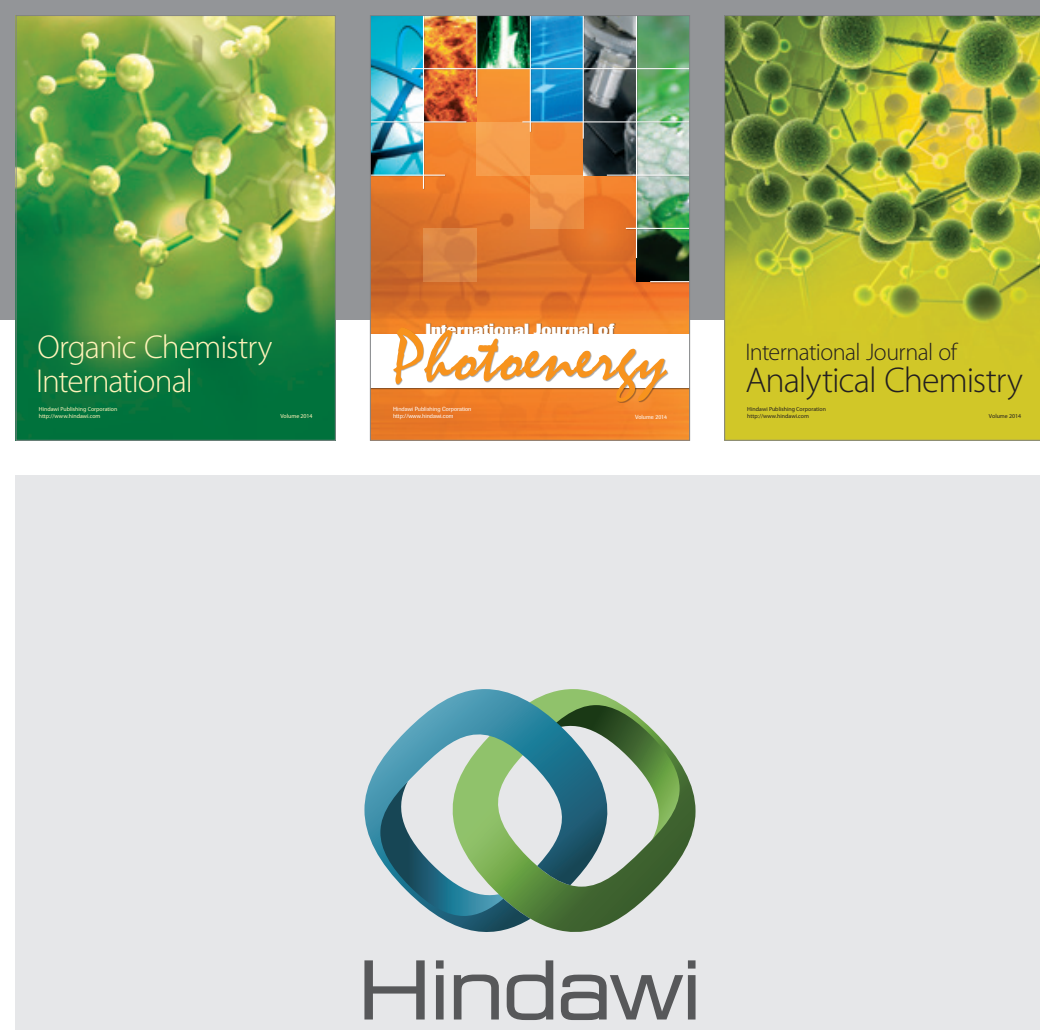

Submit your manuscripts at

http://www.hindawi.com
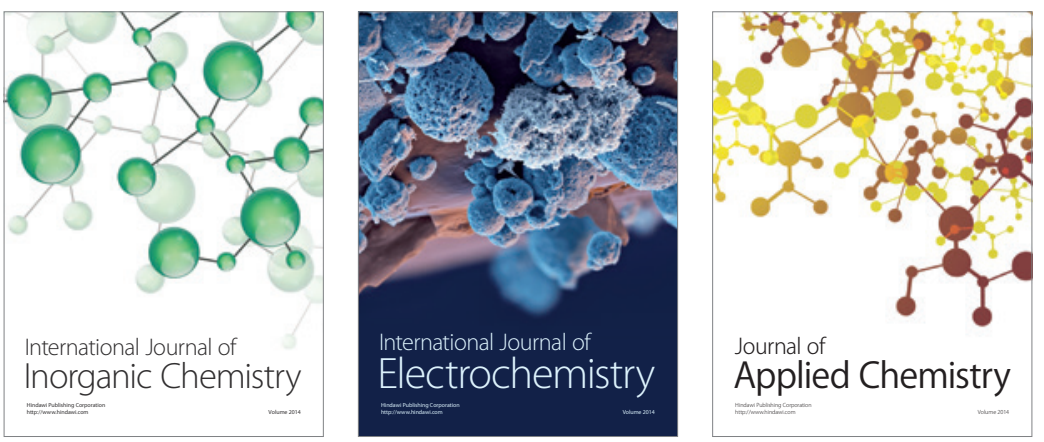

Journal of

Applied Chemistry
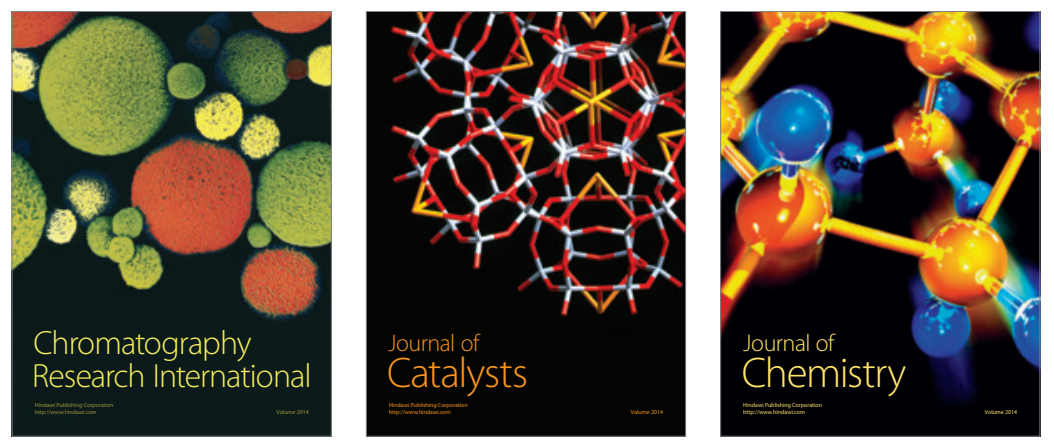
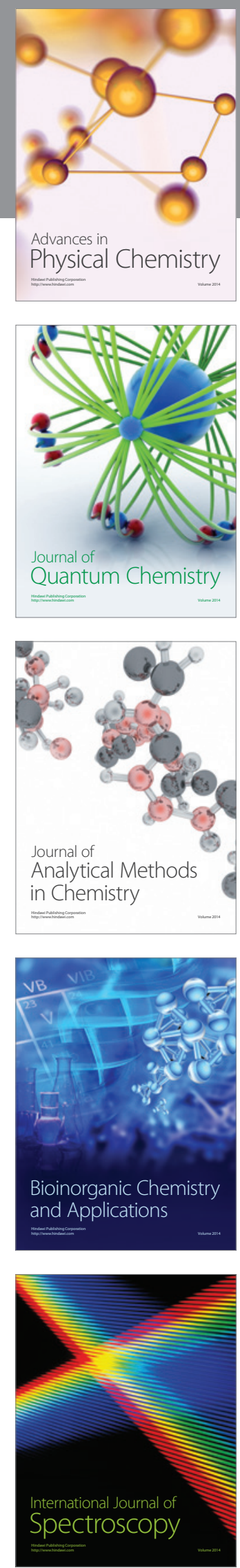